\title{
Júlia Lopes de Almeida em "retrato e prosa": a propósito dos diálogos entre as imagens da escritora e sua produção literária*
}

\author{
Michele Asmar Fanini**
}

\section{Resumo}

$\mathrm{O}$ artigo busca analisar um conjunto seleto de registros visuais sobre a escritora carioca Júlia Lopes de Almeida (1862-1934), todos eles extraídos de seu arquivo pessoal - de que fazem parte retratos fotográficos, alguns dos quais veiculados em jornais da época, três retratos artísticos e dois desenhos -, com o fito de identificar os possíveis diálogos que tais imagens estabelecem entre si e o modo como tematizam, pictórica e visualmente (seja de modo arrevesado ou não), a vinculação da escritora ao mundo das letras. O artigo revela o apreço de Júlia Lopes pela arte, "em todas as suas organizações sensíveis", e tem seu pano de fundo marcado pelo amplo diálogo que tais imagens estabelecem com um dos mais recorrentes temas presentes em seus escritos, a saber, a profissionalização literária feminina no entresséculos (XIX-XX).

Palavras-chave: Júlia Lopes de Almeida, Literatura Brasileira, Artes Plásticas, Fotografia; Gênero.

\footnotetext{
* Recebido para publicação em 1 de setembro de 2011, aceito em 6 de maio de 2012. Este artigo é resultado parcial da pesquisa de pós-doutorado que realizo no Instituto de Estudos Brasileiros da USP, para a qual conto com a supervisão dos Profs. Drs. Marcos Antonio de Moraes e Ana Paula Cavalcanti Simioni, bem como com o auxílio financeiro da Fundação de Amparo à Pesquisa do Estado de São Paulo (FAPESP), sob a forma de uma bolsa de estudos.

** Doutora em Sociologia (USP). Pós-doutoranda junto ao Instituto de Estudos Brasileiros da USP.michele.fanini@gmail.com
}

cadernos pagu (41), julho-dezembro de 2013:159-199. 
Júlia Lopes de Almeida em "retrato e prosa"

Júlia Lopes de Almeida in "Portrait and Prose": on the Dialogues between Some Images of the Writer and her Literary Production

\begin{abstract}
This article searches to make a pictorial analysis of a selected range of visual documents about the carioca writer Júlia Lopes de Almeida (1862-1934), with a view to identifying the possible dialogues among these images and the way in which they describe, pictorially, even though backwardly, the link between the writer and belletrism. These pictorial documents were taken from her personal archive, among which we can find some photographs - some of which were published on newspapers of her time -, three artistic portraits and two drawings. This article reveals, not only the fact that Júlia Lopes held the Art in high esteem, that is "in all its sensitive organizations", but it also has as its background the ample dialogue that these images establish with one of her most recurrent themes, that is, the feminine literary professionalization of the between centuries $\left(19^{\text {th }}-20^{\text {th }}\right)$.
\end{abstract}

Key Words: Júlia Lopes de Almeida, Brazilian Literature, Visual Arts, Photography, Gender. 


\title{
Introdução $^{1}$
}

\begin{abstract}
Distinguir entre conjunturas favoráveis ou desfavoráveis às memórias marginalizadas é de saída reconhecer a que ponto $\mathrm{o}$ presente colore $\mathrm{o}$ passado. Conforme as circunstâncias, ocorre a emergência de certas lembranças, a ênfase é dada a um ou outro aspecto (Pollack, 1989:8).
\end{abstract}

Uma das mais expoentes prosadoras da "belle époque tropical", cujo nome veio a ser cogitado para figurar na lista de membros fundadores da Academia Brasileira de Letras (1897), Júlia Lopes de Almeida (1862-1934) não chegou a fruir das benesses da "imortalidade" e, mais do que isso, sua ausência de tal panteão literário parece ter prenunciado o que sucederia com a escritora durante as décadas subsequentes: a parca frequência com que seu nome apareceria naquele repertório composto pelas predileções temáticas de estudiosos e críticos da literatura (Cf. De Luca, 1999, Moreira, 2003). Foi apenas a partir dos anos 1980 que o interesse pela produção literária de Júlia Lopes se fez notar, vindo a inspirar análises que, gradualmente, têm contribuído para o redimensionamento de sua relevância para a literatura brasileira, seja a partir de abordagens de cunho mais formalista, seja por meio daquelas análises voltadas para a identificação não somente dos trunfos sociais que, ladeados pelos predicados individuais, contribuíram para que amealhasse projeção e prestígio literários, como também de seus "contrapesos", i.e., daquele conjunto de constrições e injunções sociais que, por assim dizer, ofuscaram o brilho dos louros obtidos, ou, em outros termos, aqueles elementos que lhe facultaram ocupar uma posição de "relativo destaque" nesse "espaço de acirradas lutas e disputas simbólicas"

${ }^{1}$ De saída, gostaria de registrar meu profundo agradecimento a Ana Paula Cavalcanti Simioni, que foi quem enxergou nas imagens de Júlia Lopes um campo fértil a ser explorado e também a Carolina Martins Pulici, pela cuidadosa leitura. 
Júlia Lopes de Almeida em "retrato e prosa"

(Bourdieu, 1996). Por mais que tais perspectivas analíticas venham rendendo importantes publicações, elas não esgotam as possibilidades interpretativas a respeito de Júlia Lopes.

Em vista do exposto, o presente artigo pretende se debruçar sobre uma seara até então inexplorada: elegendo como fonte de inspiração e referencial teórico as contribuições provenientes da sociologia visual e da sociologia da arte, buscaremos analisar um conjunto seleto de imagens extraídas do arquivo pessoal de Júlia Lopes $^{2}$. Integram esse conjunto retratos fotográficos (alguns dos quais chegaram a ser veiculados pelos jornais da época), dois desenhos, bem como três retratos artísticos executados entre o final do século XIX e início do século XX, quais sejam, a aquarela assinada por Rodolfo Amoedo, provavelmente pintada no primeiro decênio do século $\mathrm{XX}$, bem como dois óleos sobre tela produzidos, respectivamente, por Berthe Worms, em 1895, e por Richard Hall, em 1922(?). O fito dessa análise é identificar, para além das diferentes entonações produzidas pelos diálogos entre estas imagens e representações, as correspondências que as mesmas mantêm com um dos temas recorrentes nos escritos de Júlia Lopes, a saber, a profissionalização literária feminina no entresséculos (XIX-XX), tal como retratada (seja de modo arrevesado ou não) em algumas de suas crônicas, em especial naquelas enfeixadas nos volumes Livro das Noivas ${ }^{3}$ (1914) e Eles e Elas $^{4}$ (1922).

${ }^{2} \mathrm{O}$ arquivo pessoal de Júlia Lopes esteve sob a guarda de seu neto, Claudio Lopes de Almeida, até dezembro de 2010, quando, então, passou a ser custodiado pelo Centro de Memória da Academia Brasileira de Letras. As telas aqui analisadas, bem como um seleto conjunto documental pertencente à escritora (que inclui alguns dos registros fotográficos utilizados neste artigo) continuam sob os cuidados de seu "herdeiro simbólico".

${ }^{3}$ O volume intitulado Livro das noivas foi publicado em 1896, e é fruto de uma compilação de crônicas que Júlia Lopes escreveu para o jornal Gazeta durante o ano de 1884, na coluna intitulada "Leitura Popular", que trazia como subtítulo "As Nossas Casas".

4 O livro Eles e Elas, publicado em 1910, é uma coletânea das crônicas que Júlia Lopes escreveu para o jornal de circulação nacional $O$ País, destinadas às 
Contudo, cabe aqui um relevante esclarecimento terminológico: o vocábulo "retrato" será empregado tanto para fazer menção às fotografias quanto às telas, de modo que a diferenciação entre cada um, ao longo do texto, será definida por seu complemento - "fotográfico" ou "artístico". Tal opção se deveu ao fato de as correspondências entre as imagens em questão terem falado muito mais alto do que suas contraposições, evidência essa que nos fez enxergar a nomenclatura como um recurso capaz de exprimir esse "terreno de correspondências" que tais registros visuais comungam.

Portanto, e a despeito das incontáveis e pronunciadas dissonâncias formais e técnicas existentes entre os retratos artístico e fotográfico, este artigo pretende percorrer o caminho exatamente inverso. O "corpus documental" sobre o qual nos ateremos figurará como fonte analítica privilegiada, a partir da qual buscaremos desvelar não somente os "diálogos" e os pontos de confluência existentes entre as imagens que o compõem, mas aquelas informações visuais que possam contribuir para uma melhor compreensão acerca do(s) "autorretrato(s)" de Júlia Lopes e, por conseguinte, do modo mesmo como a escritora pretendia ser (re)conhecida profissionalmente/publicamente "em uma época em que ser 'das letras' era prerrogativa masculina” (Salomoni, 2007:8).

\section{Júlia Lopes de Almeida em "retrato e prosa"}

Filha de lisboetas, nascida na cidade do Rio de Janeiro, Júlia Lopes de Almeida (1862-1934) cresceu em um ambiente literário dos mais estimulantes, cujas influências se fizeram sentir em sua escolha profissional. Mais especificamente, antes mesmo de apresentar-se como uma preferência casual, o interesse de Júlia Lopes pelo mundo das letras, precocemente aflorado, muito se deveu aos contatos que estabeleceu, por sugestão de seu pai, com

colunas "Reflexões de uma esposa" e "Reflexões de um marido". A edição aqui utilizada foi publicada em 1922. 
Júlia Lopes de Almeida em "retrato e prosa"

obras da literatura clássica portuguesa: Garrett, Herculano, Camilo Castelo Branco, Júlio Diniz, (Cf. De Luca, 1999:282-283).

Por mais que tenha obtido reconhecimento e notabilidade entre seus pares, a posição de Júlia Lopes no campo literário brasileiro jamais correspondeu àquela ocupada pelos escritores canônicos. A esse respeito, um acontecimento simbólico capaz de atestar seu "relativo destaque", i.e., tanto o considerável prestígio por ela amealhado, quanto seu pertencimento, por assim dizer, "marginal" ao campo literário brasileiro, foi, como mencionado no início deste artigo, a inclusão e subsequente exclusão de seu nome da lista extraoficial de membros fundadores da Academia Brasileira de Letras, em fins da década de 1890. Mais propriamente, à cogitação de seu nome, proposta por Lúcio de Mendonça em artigo publicado no Estado de S. Paulo, datado de 3 de dezembro de 1896, seguiu-se a decisão esmagadoramente majoritária, perpetrada por aqueles que ocupariam as primeiras quarenta cadeiras da $\mathrm{ABL}$, segundo a qual a vaga em questão seria preenchida por seu cônjuge, Filinto de Almeida, que passou a ser considerado por alguns como o "acadêmico consorte".

Fato é que muito pouco se sabe acerca dos bastidores dessa "valsa das cadeiras" envolvendo o casal Júlia e Filinto de Almeida, até porque a escritora jamais tornou público seu posicionamento acerca do ocorrido. ${ }^{5}$ Contudo, é possível assegurar que sua ausência do Silogeu brasileiro em nada arrefeceu ou intimidou seu ímpeto literário, tal como atesta a forma regular com que continuou a produzir e publicar seus escritos. ${ }^{6}$

5 Nas palavras de Pollack, "o problema de toda memória oficial é o de sua credibilidade, de sua aceitação e também de sua organização" (1989:9).

6 À exceção de A Falência (1901), A isca (1922) e Pássaro tonto (1934), Júlia Lopes publicou seus romances, primeiramente, sob a forma de folhetim, procedimento bastante comum no período. São eles: Memórias de Marta (1889); A família Medeiros (1892); A Viúva Simões (1897; A intrusa (1908); Cruel amor (1911); Correio da roça (1913); A casa verde (1932). Como contista, publicou Contos infantis (1886), escrito em parceria com sua irmã, Adelina Lopes Vieira; Traços e iluminuras (1887); Ânsia eterna (1903); Histórias da nossa terra (1907) e Era uma vez (1917). As artes dramáticas também receberam a contribuição de 
$\mathrm{Na}$ esteira dessas considerações, um aspecto interessante $e$ inexplorado da trajetória literária de Júlia Lopes relaciona-se, como dito, à atenção especial que a escritora dedicou, em diferentes fases de sua carreira, à obtenção de registros visuais que representassem $e$ perpetuassem sua imagem, senão como profissional das letras, ao menos vinculada a este universo, fossem eles fruto de procedimentos mais elaborados, tal o caso dos retratos artísticos, ou mesmo oriundos das técnicas fotográficas que então (e celeremente) se difundiam na efervescente belle époque tropical. Malgrado os diferentes procedimentos empregados, tanto as telas executadas pelos artistas plásticos, como as imagens obtidas pela lente dos fotógrafos muito dizem a respeito das intenções e pretensões de Júlia Lopes como escritora $e$, o que é importante destacar, dialogam com algumas de suas crônicas e oferecem insights para uma reflexão mais abrangente a respeito da profissionalização literária feminina na passagem do século XIX para o XX.

Dito isso, e para início de análise e comparação, a fotografia a seguir (imagem 1), datada de 1924, captura uma imagem de Júlia Lopes que, indiscutivelmente, a vincula ao "mundo literário". Recostada em uma cadeira, a modelo traz amparado em seu colo um exemplar cuja leitura se mostra, visivelmente, em andamento.

Júlia Lopes: A herança (1908) e Teatro, volume composto por três peças ("Quem não perdoa", "Doidos de amor" e "Nos jardins de Saul"). As crônicas publicadas nos jornais da época foram condensadas nos volumes Livro das noivas (1896); Livro das donas e donzelas (1906) e Eles e Elas (1910). Júlia Lopes também publicou A árvore (1916), coletânea de contos e poemas, em parceria com seu filho Afonso Lopes de Almeida; Jornadas no meu país (1920), registros sobre a viagem que fez ao sul do Brasil (o livro traz ilustrações de seu filho caçula, Albano Lopes de Almeida); e Jardim florido, jardinagem (1922), além de ensaios, conferências e traduções. 
Júlia Lopes de Almeida em "retrato e prosa"

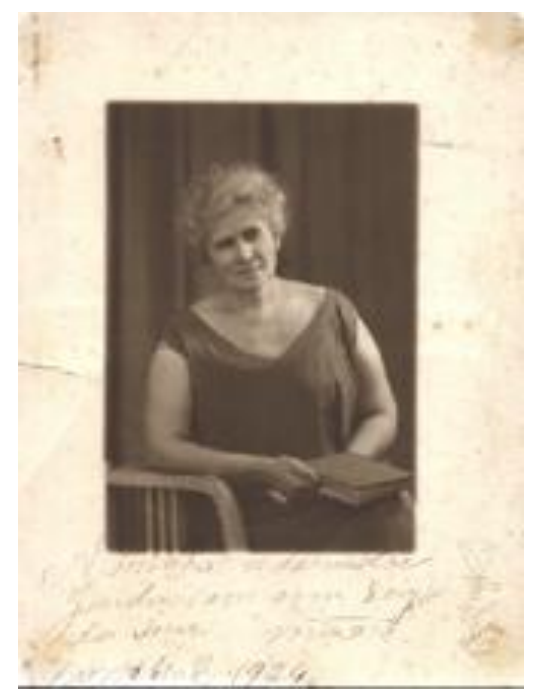

Imagem 1. Fotografia de Júlia Lopes de Almeida. Dedicatória: "À minha adorada Guida [Margarida], com um beijo de sua mãe." 7 de abril de 1924. Fonte: Arquivo pessoal de Júlia Lopes de Almeida, sob a guarda de Claudio Lopes de Almeida.

Sabendo que "alguns fotógrafos interferiam mais do que outros para arrumar os objetos e as pessoas" (Burke:28), a simplicidade cenográfica da imagem em questão parece suavizar tal presença. Mais propriamente, o explícito desalinho/desacordo entre a disposição do corpo de Júlia Lopes, voltado para a câmera, e o sutil reclinar de sua cabeça, para onde dirige um olhar fixo e esgueirado, dão a entender estar a fotografada absorta em seus pensamentos, como que instigada pela leitura, e, por conseguinte, desatenta ou despreocupada com a presença de uma lente a fitá-la.

Ainda que fruto de uma "disposição cênica", seria possível arriscar que o ato de fechar o livro, sem que sua mão direita descuidasse da marcação da página em que a leitura deveria ser retomada, traduz a ideia de uma "pausa reflexiva e temporária". Considerando-se que, de uma maneira geral, "os acessórios 
representados junto com os modelos geralmente reforçam suas auto-representações", podendo ser apreendidos como "'propriedades' no sentido teatral do termo" (Burke, 2004:32), o livro revela-se, sobretudo, um objeto simbólico: sua presença, que nada tem de fortuita, associa a fotografada a determinada prática. E tal associação contrapõe-se justamente ao fato de, nos retratos do período, "a mulher raramente aparece[r] portando algum objeto", à exceção daqueles que vêm a reforçar sua "feminilidade", tal o caso dos espelhos, leques etc. (Carvalho, 2008:231).

Somado a isso, e considerando-se que "a cortina é o que melhor representa o sentido de interior" (id.ib.:97), a sobriedade da vestimenta de Júlia Lopes, reforçada por seu tom escuro $e$ monocromático, a displicência do penteado, assim como a ausência de qualquer tipo de adorno (brincos, colar, pulseira, broches, camafeus etc.) parecem situá-la no ambiente doméstico, de modo que a pose capturada, seja ela espontânea ou forjada, traduz a potência de certa disposição corporal na construção da imagem pretendida, especialmente porque, dessa maneira, o gosto pela leitura e sua prática são apresentados como um hábito cotidiano.

Em sugestivo diálogo com as informações visuais que emanam desse retrato, a crônica "Os livros" lança luz sobre essa temática, mas a partir de uma perspectiva, por assim dizer, contrastante: sem esconder certa resignação, Júlia Lopes lamenta o fato de o hábito da leitura haver sido considerado, por tanto tempo, uma prática indesejável às mulheres. Segundo a autora, "os pais antigos proibiam a leitura às filhas, afirmando que os livros eram os piores inimigos da alma". Para mantê-las distanciadas desses "perigosos conselheiros", responsáveis pela perdição feminina, simplesmente "não as ensinavam a ler!" (Almeida, 1914:35).

Ao reportar-se a sua própria época, a cronista lembra que a crescente alfabetização feminina não correspondeu à ampliação significativa do número de leitoras, especialmente porque ainda havia "chefes de família que abomina[va]m os livros, ordenando às filhas que não [tocassem] nunca em semelhante coisa" 
Júlia Lopes de Almeida em "retrato e prosa"

(id.ib.:35). Em seguida, atenta para o desdobramento social desse "desencorajamento", ao mencionar a aridez de mulheres leitoras e a parca procura pela literatura nacional e de "qualidade":

É raro encontrarem-se nas nossas salas duas senhoras que falem de literatura, mostrando interesse pelos bons autores, principalmente pelo de seu país! Do jornal leem o folhetim, isto é, o romance de enredo, onde as deleitam as cenas imprevistas, as astúcias de lacaios, os véus negros de adúlteras em entrevistas amorosas, e os lampejos de espada no campo da honra! (id.ib.:36) ${ }^{7}$

Voltando à imagem 1, os poucos elementos que compõem o "arranjo cenográfico", para utilizar uma expressão de Annateresa Fabris, tal o caso da cortina, que homogeneíza o fundo da fotografia, contribuem para que a atenção esteja voltada exclusivamente para Júlia Lopes, cuja apresentação corporal é não menos do que a tradução explícita de uma ação interrompida. Não seria arriscado afirmar que os indícios da leitura em progresso afiguram-se, aqui, como o grande "motivo" desse retrato fotográfico, fazendo crer que é exatamente em sua porção menos visível e óbvia, a saber, na dimensão do implícito, do indicial, do não-revelado, do sugerido, correntemente relegada pela imponência do que se revela flagrante, que residem aqueles detalhes significativos que a fotografia pretende informar (Martins, 2008). ${ }^{8}$

7 Porém, na crônica "Mulher brasileira", que integra o Livro das donas e donzelas (1906), Júlia Lopes considera que "apesar da antipatia do homem pela mulher intelectual, que ele agride e ridiculariza, a brasileira de hoje procura enriquecer a sua inteligência frequentando cursos que lhe ilustrem o espírito $e$ lhe proporcionem um escudo para a vida, tão sujeita a mutabilidades".

8 Por mais que "o fotógrafo não [seja] o autor de um trabalho minucioso, e sim o espectador da "aparição autônoma e mágica de uma imagem química" (Rouillé apud Fabris, 1991:14), o retrato fotográfico em questão distancia-se, por detalhes encobertos, da obviedade do que foi mecanicamente capturado. Para falar como Miriam Moreira Leite (1993:37), "para a leitura da documentação fotográfica 
Coetâneo e em sintonia com a imagem $\mathbf{1}$, o retrato a óleo assinado por Richard Hall (imagem 2) no início da década de $1920^{9}$ e, posteriormente, inclú́do no livro Dona Júlia (1938), de autoria de Filinto de Almeida, também apreende Júlia Lopes de Almeida no exato momento de interrupção da leitura. A mão esquerda, que repousa improvisadamente sobre seu colo, segura os óculos que, ao que tudo indica, haviam sido removidos, há pouco, de sua face.

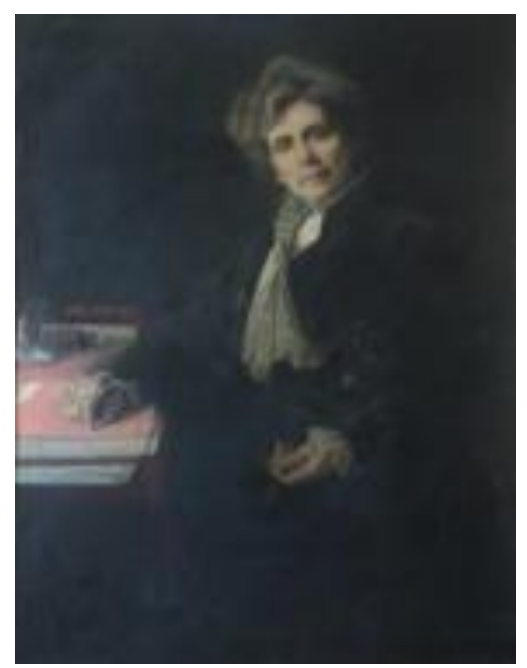

Imagem 2. Retrato a óleo de Júlia Lopes de Almeida, pintado por Richard Hall, 1922(?). Imagem também reprografada e incluída no livro Dona Júlia (1938), de Filinto de Almeida.

Sendo a presença dos óculos - objeto cuja funcionalidade supõe, no caso de Júlia Lopes, o exercício da leitura/escrita e a prática literária em si -, expressão material do reparo aos danos

importam menos a composição, a focalização e a exposição que os elementos revelados pelo conteúdo, ainda que, entrevistos, pareçam mais do que apareçam". 9 De acordo com Cláudio Lopes de Almeida, o retrato a óleo em questão foi confeccionado quando Júlia Lopes contava, aproximadamente, 60 anos. 
Júlia Lopes de Almeida em "retrato e prosa"

que anos de esforço causaram às vistas, sua centralidade para a nossa análise reside em seu atrelamento "à atividade intelectual" $e$, o que é relevante sublinhar, às "fortes conotações masculinas" de que se investiam em virtude de tal vinculação (Carvalho, 2008:58). Isso porque tal acessório, considerando-se a passagem do século XIX para o XX, cristalizava e exprimia as "diferenças de gênero no uso da visão, essencialmente baseadas na valorização do uso contínuo para o homem e do uso rápido e ocasional para as mulheres" (id.ib.:28). ${ }^{10}$

Muito embora representada sem os óculos, Júlia Lopes os deixa explícitos ao olhar do artista plástico, dando a entender que o que se revela ocasional é o aprumo visual, essas pequenas intervenções na aparência capazes de lhe facultar uma melhor "apresentação de si". Em outros termos, o cuidado estético não obnubila o cuidado intelectual. A imagem faz coro, embora estritamente em termos cênicos, à constatação de Carvalho (2008:63), segundo a qual o uso "intermitente" dos óculos pelas mulheres encontrava explicação em certo apuro estético, especialmente porque "a expressão do olhar, os traços do rosto eram elementos importantes na concepção de beleza", de sorte que "obliterar ou reduzir os olhos com um instrumento significaria redução de feminilidade" (Carvalho, 2008:63).

Ainda em relação à imagem 2, a mão direita de Júlia Lopes, aquela que, durante os arroubos criativos, detém a pena, e que também folheia cada página lida, apoia-se cuidadosamente sobre a mesa de estudos, vindo a reforçar a ideia de que a escritora fora

${ }^{10}$ Vânia Carneiro de Carvalho reflete sobre "o uso sexuado dos óculos", tendo como referencial privilegiado os óculos que integram as coleções do Museu Paulista, bem como retratos do século XIX e início do XX, pertencentes à mesma instituição (2008:28). Tal como lembra a historiadora, "um confronto entre óculos femininos e masculinos no acervo do Museu Paulista nos informa sobre o uso (e valorização) diferenciado da visão entre homens e mulheres. Não é por acaso que, entre uma dezena de óculos depositados nessa instituição, a maioria pertenceu a personalidades ilustres, todas masculinas. A única peça feminina é um face-à-main, ou seja, óculos com suporte para a mão, o que nos indica o uso da visão de forma rápida e superficial na observação e leitura" (2008:61). 
surpreendida em pleno exercício de sua profissão. A pose de Júlia Lopes, cuja altivez encontra reforço em seu olhar inquisidor $e$ judicativo, faz com que o "momento de pausa" adquira os contornos de uma "intromissão inconveniente", justamente porque à rigidez de sua expressão e traços fisionômicos correspondem os retoques rapidamente promovidos pela escritora em sua postura, no intuito de adequá-la às exigências de um retrato artístico e, arriscamos dizer, "apressar" a sua confecção, para logo retornar ao trabalho. Além disso, o ligeiro aprumo promovido por Júlia Lopes em sua imagem, no intuito de melhor "exibir-se" ao artista plástico - ao retirar os óculos e interromper a escrita/leitura -, como que recrudesce, de forma arrevesada, os fortes indícios que a vinculam ao ofício de escritora.

Não seria apressado, portanto, supor que esse jogo cênico adquire maior visibilidade quando pensado em termos das "atribuições de gênero aos objetos", resultantes da prática social reatualizada diariamente pela própria prática social, tornando-os "emblematicamente sexualizados" (Carvalho, 2008:44). Nesse sentido, a presença do livro (considerando-se as imagens 1 e 2), assim como os elementos que compõem o retrato de Hall, tal o caso dos óculos e mesmo da mesa de trabalho - representação material do esforço intelectual, dos momentos de reflexão, criação e estudo (id.ib.:47-48), ao aludirem ao universo masculino, deixam entrever certo desajuste/descompasso entre "gênero e objetos" e, em um outro nível, entre "gênero e profissão". ${ }^{11}$

Longe, pois, de se afigurar como uma "feliz coincidência", muitas são as passagens da obra de Júlia Lopes que tematizam tais (des)ajustes/(des)compassos, em especial no concernente à apreensão da leitura e da produção literária como práticas interditas às mulheres. Além da já referida crônica "Os livros", outro exemplo notório é a crônica "Cada vez que...", ao

${ }^{11}$ Optamos pelos vocábulos "desajuste" e "descompasso", pois parecem traduzir com propriedade o quanto "a presença de objetos com funções instrumentais são marca importante da presença masculina no espaço da casa" (Carvalho, 2008:128). 
Júlia Lopes de Almeida em "retrato e prosa"

evidenciar o desalinho entre o desejo, manifesto pela personagem, de acompanhar a leitura com seu marido, e a recusa deste em compartilhar com a esposa uma "atividade a ela não afeita":

Quando me debruço sobre o ombro de meu marido para seguir-lhe a leitura, percebo no gesto suave com que ele afasta o livro dos meus olhos, esta significação:

- Tu não entendes disto... vai-te embora...

Eu retomo o meu lugar, um tanto envergonhada da ousadia, e ele segue sozinho nessas altas regiões do espírito, que me são vedadas. O meu plano é outro, cá embaixo; $e$ arrojam-me para ele com tão repetidos impulsos, que começo a magoar-me (Almeida, 1922:25-26).

Por seu turno, a crônica "A mesa" ilustra muito bem o quanto, por exemplo, os "arranjos de mobiliário" produzem e reproduzem "diferenças de natureza sexuada, introjetadas de maneira inconsciente e automática nos comportamentos cotidianos" (Carvalho, 2008:20). Mais propriamente, o móvel que dá nome ao texto, em virtude de seu "apelo gregário", é aquele cujo significado o transcende: não se trata propriamente daquela mesa convidativa às atividades intelectuais, solitárias, mas daquele móvel em torno do qual a família se reúne para realizar suas refeições. Aliás, uma mesa "atraente e risonha", lembra a cronista, é aquela que recebeu a "demão feminina": "linho alvo, flores frescas, cristais límpidos, porcelana e talheres bem tratados" (Almeida, 1914:89).

Na crônica em questão, a referência a certos aspectos da rotina doméstica e à divisão de papéis a ela correspondente vai ao encontro das observações encaminhadas por Carvalho, para quem "o homem, mantenedor da família e sua linguagem, está associado à função provedora. A ele é outorgada simbolicamente a responsabilidade pelo alimento ( $e$ não pelo seu processamento $e$ apresentação à mesa)" (2008:120): 
Não falta quem sustente que a mesa é a base da felicidade na vida do homem, e esses confessam reconhecer em Brillat-Savarin um sábio de belas teorias e fácil prática...

A alimentação influi no caráter, afirmam sábios; e mais ainda que no caráter é a sua influência poderosa na aptidão para o trabalho. Vá uma pessoa entregar-se a uma tarefa delicada, a um trabalho intelectual, a um estudo sutil, depois de um jantar grosseiro e pesado! A dificuldade da digestão produzirá o enervamento geral, embotando o cérebro e perturbando o pensamento.

A escolha dos alimentos deve ser feita com inteligência e critério.

Disto resulta que toda mulher deve ser um pouco cozinheira; que, do mesmo modo que sabe fazer o seu vestido de sura ou de linho, deve saber escrever uma carta, ler um livro, receber uma visita, ou fazer a massa dourada, macia e fina, de uma torta de aves, ou uns bons pasteis folhados... (Almeida, 1914:93). ${ }^{12}$

Apenas para fins analíticos, e em termos absolutos, é possível dizer que a mesa de jantar e a mesa do escritório não apenas prefiguram uma relação dicotômica (que abriga antinomias como individual x coletivo; solenidade $\mathrm{x}$ privacidade; trabalho x confraternização; isolamento x interação), como dão a ver suas "filiações a gêneros" (Carvalho, 2008:121).

\footnotetext{
${ }^{12}$ Ainda que muitas crônicas de Júlia Lopes tematizem as assimetrias entre os gêneros, especialmente lançando luz sobre a importância do letramento feminino, bem como de sua profissionalização, tantas outras apresentam-se como espécies de manuais de aconselhamento, cujos "preceitos (...) pressupunham uma mulher disponível para o gerenciamento doméstico, livre das atividades reconhecidas como 'produtivas', com tempo para aprimorar conhecimentos de desenho, pintura, música, bordados e, com isso, tornar-se motivo de orgulho para o marido nas recepções sociais -, a própria natureza do manual indica um esforço em disseminar esse padrão em outras camadas da população, sendo, portanto, um indicador importante da sua força hegemônica a partir da elite" (Carvalho, 2008:30-31). A crônica "A mesa", por exemplo, é ilustrativa dessa modalidade textual marcadamente elitista, aproximando-se, pois, de um manual de etiquetas.
} 
Júlia Lopes de Almeida em "retrato e prosa"

Contudo, nos retratos fotográficos abaixo (imagens 3 e 5), que chegaram a ser reproduzidos nos jornais da época (imagens 4 e 6), o aparente (des)ajuste entre "gênero e objetos" parece dissolver-se em sugestiva complementaridade: dessa vez, Júlia Lopes exibe os óculos a desempenhar toda a sua funcionalidade, muito embora os traços intelectuais que deles emanem vejam-se suavizados pelos demais adornos que compõem seu visual, quais sejam, no primeiro retrato, o colar de pérolas e o arranjo floral, espécie de broche a incrementar o monocromatismo e a lisura do tecido de sua blusa (ou vestido) e, no seguinte, o conjunto formado pelo colar de pérolas e o par de brincos e, em destaque, a aliança.
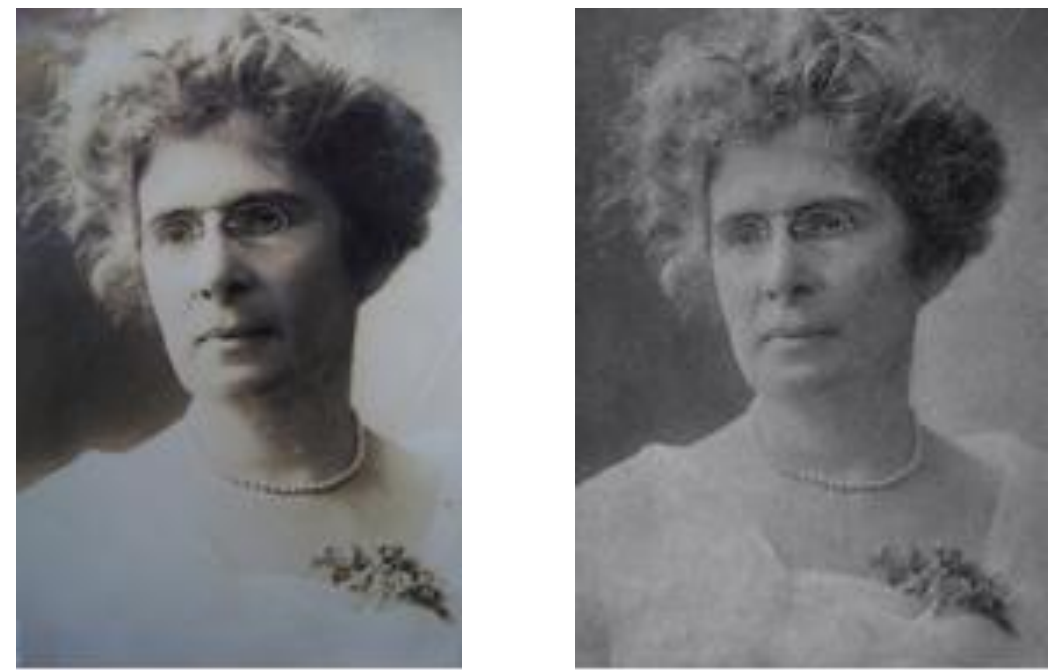

Imagens 3 e 4. Da esquerda para a direita, fotografia de Júlia Lopes de Almeida [s.d.]. e sua versão veiculada no jornal carioca $A$ Noite, 4 jul. 1923, bem como n'A Notícia [s.d.]. 

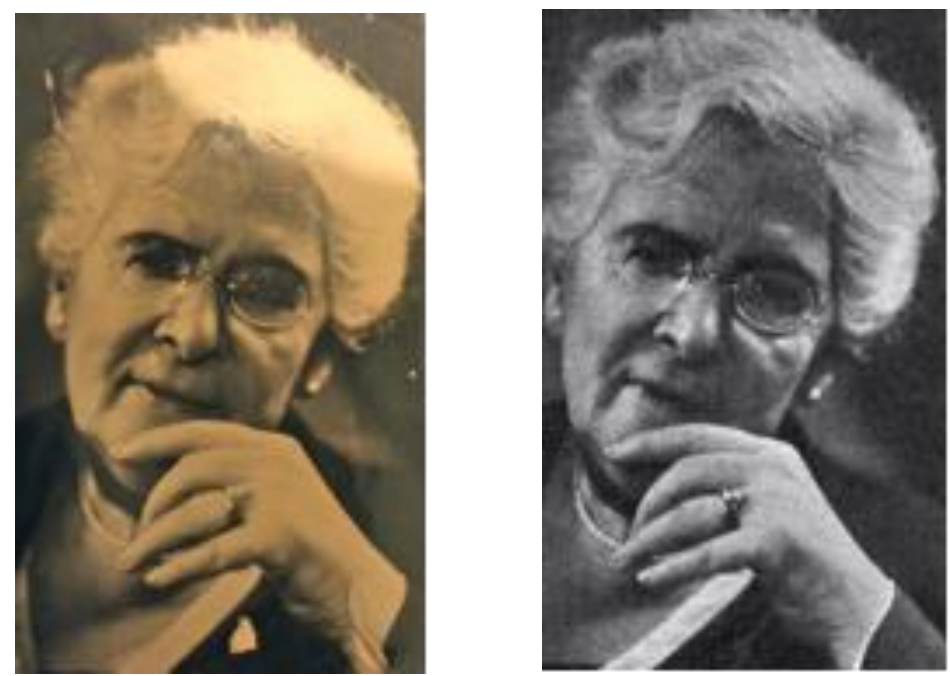

Imagens 5 e 6. Da esquerda para a direita, fotografia de Júlia Lopes de Almeida [s.d.], e sua versão veiculada na imprensa, em 1962, em virtude do centenário de seu nascimento.

O significativo lapso temporal existente entre ambas as fotografias confere aos objetos que as particularizam o status de "biográficos", ao "assentirem" à fotografada sua posição no mundo, sua identidade (Bosi, 1991:441). Nos termos de Bosi,

são estes os objetos que Violette Morin [em artigo publicado em 1969] chama de objetos biográficos, pois envelhecem com seu possuidor e se incorporam à sua vida: o relógio da família, a medalha do esportista, a máscara do etnólogo, o mapa-múndi do viajante. Cada um desses objetos representa uma experiência vivida. Penetrar na casa em que estão é conhecer as aventuras afetivas de seus moradores. Daí vem a timidez que sentimos ao entrarmos em certos quartos em que os objetos nos revelam quem é o seu dono (Bosi, 1991:441). 
Júlia Lopes de Almeida em "retrato e prosa"

A propósito, com título homônimo, Júlia Lopes dedica uma de suas crônicas às joias, ornamentos que aparecem vinculados à maturidade feminina. Apresentadas como uma espécie de nobres sucessoras das flores, enfeites, por excelência, ostentados pelas jovens que contam até vinte anos, as joias são requisitadas pelas mulheres maduras por lhes "devolverem", de alguma forma (no caso, literal e artificialmente), aquele brilho que o passar dos anos lhes usurpara (Almeida, 1914:64-65):

Até os vinte anos uma rosa, um ramo de violetas ou qualquer outra flor, equivale a um diamante de preço. Para que o brilho emprestado de uma pedra fina, se os olhos da gente nova tem tanto lume, tanta expressão e tanto fulgor?

As flores foram feitas para a mocidade, quadra da suprema poesia e do mais doce perfume da existência.

As pedras... para a segunda quadra, isto é - para os dias em que o entusiasmo é mais prático do que imaginativo, em que já não há na mulher o mesmo desprendimento, a mesma sutileza, nem a mesma alma cândida e sonhadora que se aninha no peito das jovens.

Olha-se menos para a lua... e para as estrelas... e para as rosas; e pensa-se um pouco mais nos colares de brilhantes.

A pérola, eclipsada pelo protagonismo encenado por aquelas joias ofuscantes, "entra mais tarde nas predileções da mulher, quando o seu espírito já não se deixa levar pelo efêmero, o vistoso e o ornamental, e penetra no mundo da poesia e da meditação" (id.ib:60-61). Nessa linha de juízo, seria possível considerar que o colar de pérolas ostentado por Júlia Lopes, "em sua opacidade enluarada", é menos um índice representativo de sua vaidade, de seu comedido apego estético, que um adereço alusivo àquelas "atividades superiores do espírito" (Carvalho, 2008:334), àquela 
dimensão artística de sua existência que, mesmo de forma cifrada $e$ simbólica, merecia ser revelada e, destarte, perenizada. ${ }^{13}$

À guisa de ilustração, as figuras que seguem, assinadas, respectivamente, por Alberto Lima e Carlo Bim, assemelham-se a versões estilizadas (ou retraduções artísticas) das fotografias $\mathbf{3}$ e $\mathbf{5}$. A primeira delas (imagem 7) foi incluída na primeira página do $E X$ LIBRIS Comemorativo do Centenário de Nascimento de Júlia Lopes de Almeida (Rio, 1962, n 550), uma iniciativa da Academia Carioca de Letras, que contou com a colaboração do Instituto Histórico e Geográfico do Rio de Janeiro. No desenho em questão, a imagem de Júlia Lopes recebe uma inusitada "moldura": referências à sua atuação profissional (escritora $e$ jornalista), às suas publicações $e$ a alguns dos jornais em que atuou como colunista (O País, Gazeta de Campinas, A Semana, Correio Paulistano). ${ }^{14}$

\footnotetext{
${ }^{13}$ Nas palavras de Souza, "as preocupações do espírito, estas eram privativas do homem, dono das artes, da literatura e do destino de seus semelhantes" (1987:99).

${ }^{14}$ Tal como assinala Paixão (1987:21), Júlia Lopes atuou como colaboradora nos seguintes jornais e periódicos: Almanaque de Notícias (1897-1891), A Bruxa (1897), A Estação (1888-1891), Gazeta de Notícias (1888-1894), Ilustração Brasileira, Jornal do Brasil, Kosmos, O Mundo Literário, O País, A Semana (1885-1887, 1894), todos do Rio de Janeiro; Revista do Brasil, Revista dos Novos (1885-1886), de São Paulo, SO; Gazeta de Campinas, Campinas, SP.
} 
Júlia Lopes de Almeida em "retrato e prosa"

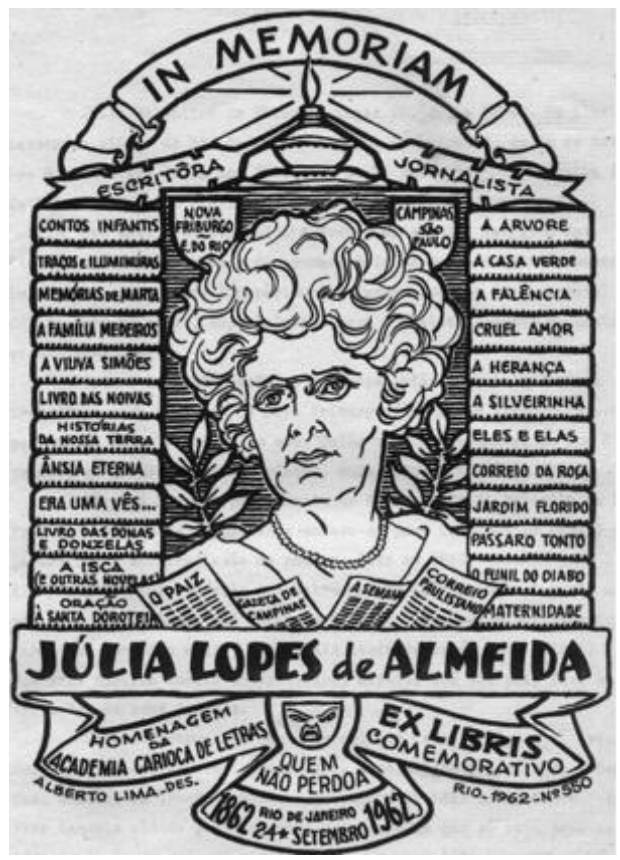

Imagem 7. Ilustração de Júlia Lopes de Almeida, assinada por Alberto Lima, que consta do EX LIBRIS Comemorativo de seu centenário de nascimento;

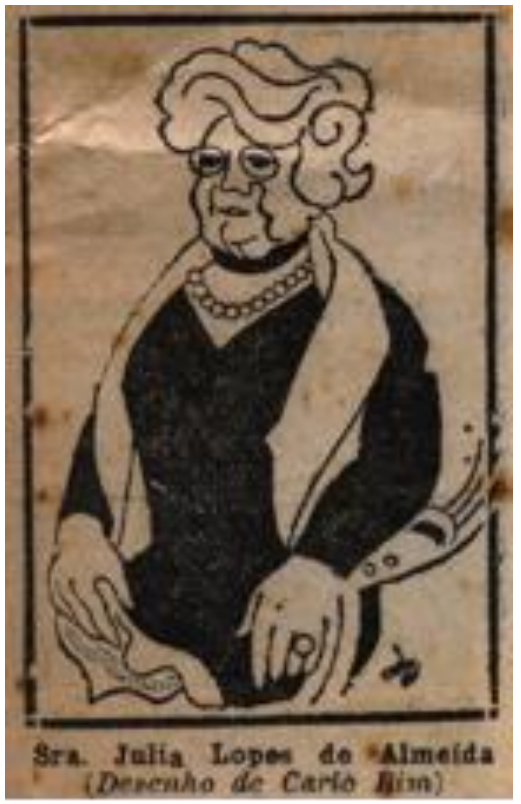

Imagem 8. Caricatura da escritora elaborada por Carlo Bim [s.d.]. 
Já a fotografia abaixo -, que parece sustentar a afirmação de Benjamin (1996:93-95), a respeito dos pontos de confluência que "esta expressão visual com trânsito na arte" (Martins, 2008:34) mantinha com o retrato artístico - faz lembrar o "retrato cenográfico" produzido "em estúdio fotográfico"15, cujo propósito era traduzir em termos de mobília e "artefatos", o bom gosto, as aspirações e pretensões do fotografado, por meio do qual o cliente poderia obter "uma visão concreta e ao mesmo tempo ficcional de sua inserção no ambiente decorativo requintado" (Carvalho, 2008:37-38), espécie de "materialização das noções de dignidade, opulência e bom gosto aplicadas à figura [do fotografado]" (Carvalho e Lima, 2005:277-288).

\begin{abstract}
As fotografias produzidas em estúdio e que apresentavam o retratado mergulhado em um cenário considerado artístico eram tidas como demonstração de bom gosto e serviam para atestar a capacidade de expressão criativa e progresso pessoal dos proprietários. Eram, portanto, afirmações de status e compartilhavam com os demais objetos de decoração a tarefa de declarar o comprometimento com a cultura burguesa (id.ib.:93).
\end{abstract}

A ressalva, porém, reside no fato de que, no caso da imagem 9, o fotógrafo viu-se dispensado da necessidade de forjar uma "ambientação ilusória" (Schapochnik, 2006:464), já que o "estúdio" era a própria sala de leitura de Júlia Lopes, tal como esclarece seu neto, Claudio Lopes de Almeida, cômodo este "bem

${ }^{15}$ O surgimento dos "ateliês fotográficos" particulares foi sintomático da aposta no "incremento cenográfico", caracterizado pela incorporação de "dispositivos para fixar a cabeça ou o joelho [do fotografado]" seguidos por "outros acessórios, como nos quadros célebres", tais como a coluna e a cortina (Benjamin, 1996:98; Carvalho, 2008:37), espécie de "materialização das noções de dignidade, opulência e bom gosto aplicadas à figura [do fotografado]" (Carvalho e Lima, 2005:277-288). 
Júlia Lopes de Almeida em "retrato e prosa"

guarnecido" (Almeida, 1914:41), "decorado com os ícones da burguesia citadina" carioca (Carvalho, 2008:37). ${ }^{16}$

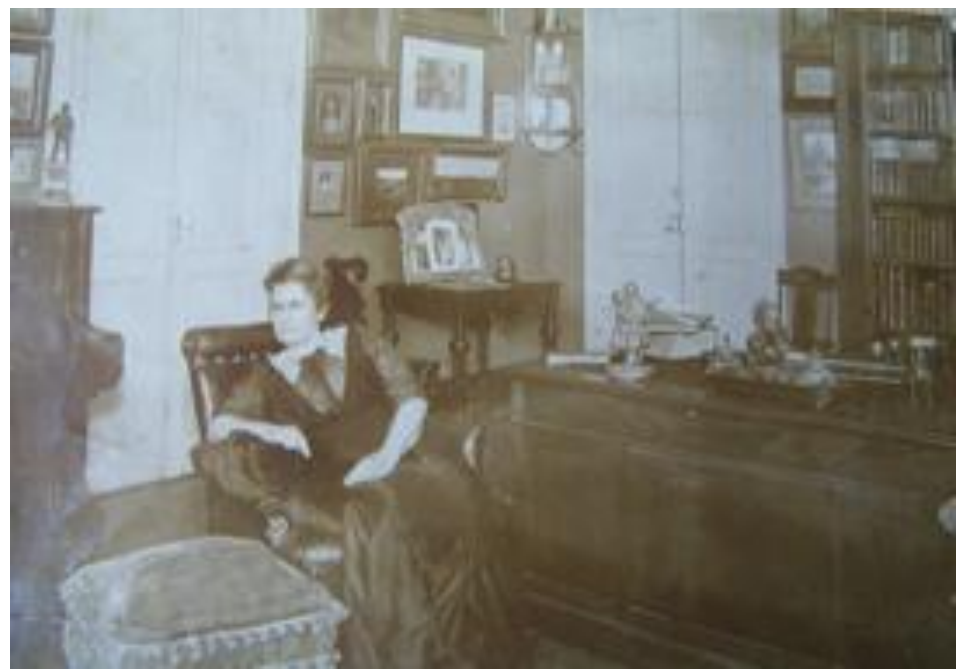

Imagem 9. Júlia Lopes em seu escritório/sala de leitura.

Referindo-se às características gerais de um escritório, "lugar explicitamente reconhecido como arena do chefe da casa", "de absoluta privacidade masculina" (id.ib.:137-138), Carvalho destaca a "função instrumentalizadora do mobiliário" que o particulariza, ao conjugar conforto e praticidade.

Como não podia faltar, o escritório de Júlia Lopes conta com a presença de uma estante farta em livros, inegável alusão à "profissão de natureza intelectual", então considerada "atribuição masculina do mais alto prestígio" (id.ib.:48). Curiosamente, na crônica "Os livros", anteriormente mencionada, a escritora estabelece uma irreverente correspondência entre a "estante de

${ }^{16}$ Schapochnik (2006:494) lembra que a estilização do espaço doméstico guarda inúmeras pistas relevantes para a compreensão "da autoimagem de seus habitantes". 
uma mulher" e um altar. Em termos metafóricos, sendo a estante feminina "um altar", a leitura afigura-se, no limite, como uma prática "sagrada". Levando-se em conta as acepções de que se investe esse vocábulo, tanto é possível pensar nos livros como dignos de devoção, quanto na leitura como hábito que não pode ser violado ou infringido, i.e., como aquilo que é "sagrado":

A estante de uma mulher de espírito e coração, isto é, de uma mulher habilitada a apreender e conservar o que ler; que souber que isso a instrui, a torna apta a dirigir a educação dos filhos, dando-lhe superioridade e largueza de vistas; a estante de uma mulher inteligente e cuidadosa, que ama os seus livros, não como um mero adorno de gabinete, mas como a uns mestres sempre consoladores e sempre justos, essa estante é um altar onde o seu pensamento vai, cheio de fé, pedir amparo numa hora de desalento, e conselho num momento de dúvida (1914:38; destaques nossos).

Voltando ao aposento, é possível também notar uma expressiva "coleção" de imagens (porta-retratos, retratos e pequenos quadros), estes dois últimos dispostos de modo a "forrar" as paredes, como que a exprimir simbolicamente "as veleidades pessoais e o prestígio social" da escritora (Schapochnik, 2006:502). Merece atenção, tanto pela sua dimensão, quanto pelo local privilegiado que lhe fora destinado, a aquarela executada por Rodolfo Amoedo (imagem 10). Ademais, salta aos olhos a imponência da poltrona de couro, móvel também "associado ao homem" e ideal "para longas permanências", na qual Júlia Lopes encontra-se como que "entronizada" - mas não sem apoiar seu braço sobre uma almofada (Carvalho, 2008:67,99). ${ }^{17}$

Convém salientar que a fotografia em questão contrasta com os diferentes anúncios publicitários compulsados por

${ }^{17}$ É necessário sublinhar que, para além das alfaias, "certas matérias-primas" também são "apropriadas sexualmente". A esse respeito, "nenhuma matériaprima possui mais conotações masculinas do que o couro" (Carvalho, 2008:65). Por seu turno, a almofada como que sugere a nidificação do lar. 
Júlia Lopes de Almeida em "retrato e prosa"

Carvalho, mais especificamente com aqueles que apreendiam as mulheres em ambientes domésticos, próximas às cortinas, almofadas e abajures, na medida em que elas pareciam não "usufruir da comodidade que essas peças ofereciam" (id.ib.:105):

O que chama a atenção nas imagens é a presença da almofada como adorno feminino, sugerindo muito mais uma afinidade do que qualquer modo de uso efetivo. Esses objetos não estão no cenário como peças de conforto, pois como tais apresentam-se incompatíveis com as posturas corporais das figuras femininas que as utilizam. As mulheres que vemos não estão relaxadas, em posição de descanso, mas eretas, em alguma atividade (como maquiando-se, segurando um calçado) ou expondo-se em lingeries ou coletes. As cortinas, abajures e almofadas estão ali como partes ou extensões do corpo feminino, que juntos produzem o ambiente confortável e artístico oferecido para o aconchego masculino (id.ib.:105).

A conjugação de tais elementos, ao respaldar-se no fato de, "ao que tudo indica, as apropriações do masculino pelo feminino [serem] muito mais interditas do que o seu contrário" (id.ib.:293), oferece um quadro pouco comum, espécie de ilustração às avessas da bem observada "contiguidade ou condutibilidade entre corpo feminino, objeto e espaço doméstico" (id.ib.:105). ${ }^{18}$

Contudo, a aspereza e a robustez do mobiliário são amenizadas pela presença de um piano, pelos "pequenos objetos

\footnotetext{
${ }^{18}$ Carvalho pontua que "os ambientes de trabalho destacados nas revistas [entre 1870 e 1920] são as mesas e as escrivaninhas, sinônimos de atividade intelectual entendida como produção de ideias, mas também como contabilidade, planejamento, gerenciamento, legislação e comunicação expressos por meio de suportes materiais relativos à escrita e à fala. Sobre as mesas figuram papéis, livros, tinteiros, canetas, telefones, carimbos, arquivos, máquinas de escrever. Seus usuários se deixam fotografar quase sempre sentados, concentrados na escrita ou na leitura de algum documento. São poucos os que olham para a câmera. $O$ prestígio da atividade intelectual para o homem estimula a exibição de si mesmo em situações de trabalho" (2008:150, destaques nossos).
} 
arranjados sobre a mesa", pelas estatuetas, pela já citada almofada e pelo módulo que atua como uma espécie de prolongamento da poltrona, sobre o qual é possível descansar os pés durante a leitura (item aqui incluído dadas as suas características materiais, em termos de tecido e estofamento) (id.ib.:148) ${ }^{19}$ A esse respeito, vale lembrar que na crônica "Belas Artes", Júlia Lopes encontra na literatura exemplo elucidativo do quão o "gênero" parece "incrustar-se" em certos objetos/artefatos: "José de Alencar observa, em um dos seus romances, que o piano é para a mulher o mesmo que o fumo é para o homem, - uma distração. Outros carregarão mesmo - um vício" (1914:47).

Ainda compondo esse rol de imagens de Júlia Lopes de Almeida, todas elas alusivas à sua vinculação ao universo das letras, localizamos em seu arquivo particular a aquarela executada por Rodolfo Amoedo (imagem 10), cujas semelhanças com a tela de Richard Hall (imagem 2), bem como com as ilustrações veiculadas pela imprensa merecem ser descortinadas.

${ }^{19}$ Tal como assinala Carvalho, "a continuidade de motivos ornamentais (arranjos florais, pássaros, ramagens) ou de matérias-primas e técnicas (plumas, sedas, rendas, estampas pintadas à mão) entre diversas categorias de objetos como leques, vidros de perfume, caixa de joias, chapéus, almofadas, trabalhos manuais nos mostram como são concretizadas nos objetos noções como harmonia, bom gosto, elegância, delicadeza, que encontram abstratamente referidas na literatura como definidoras do ser feminino" (2008:27-28; destaques nossos). 
Júlia Lopes de Almeida em "retrato e prosa"

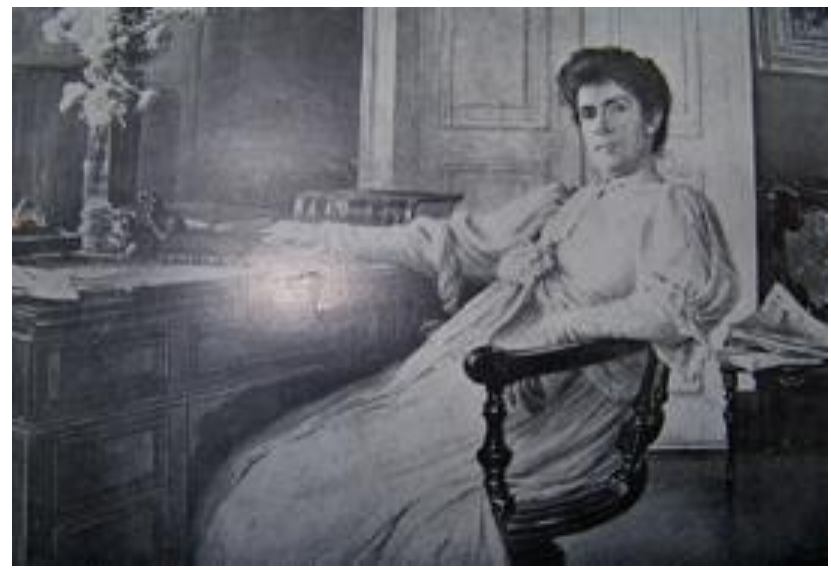

Imagem 10. Aquarela de Rodolfo Amoedo, provavelmente pintada no primeiro decênio do século XX.

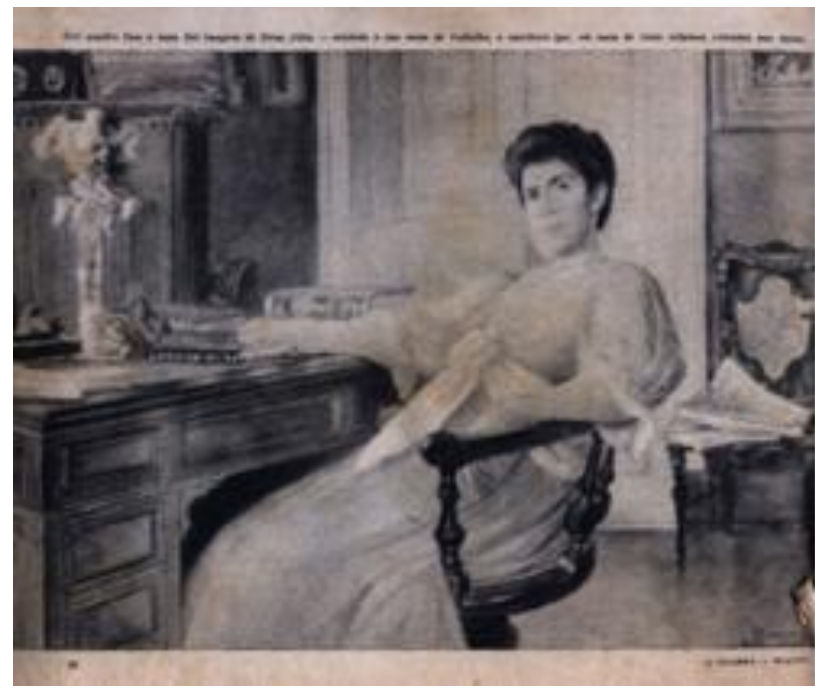

Imagem 11. Versão da Aquarela de Amoedo publicada na revista $A$ Cigarra [s.d.]. Legenda: "Este quadro fixa a mais fiel imagem de Dona Júlia - sentada a sua mesa de trabalho, a escritora que, em mais de vinte volumes, retratou sua época". Fonte: Arquivo pessoal de Júlia Lopes de Almeida, sob a guarda de Claudio Lopes de Almeida. 
O olhar penetrante e altivo da escritora, como a exprimir certo incômodo por ver-se interrompida, assemelha-se à representação de Hall, embora pareça mais acentuado na presente aquarela. No entanto, a informalidade da indumentária da escritora nesta última contrasta com a seriedade do traje em que é retratada por Richard Hall. É como se a primeira expusesse Júlia Lopes a exercer a profissão de escritora, em seu ambiente de trabalho/escritório, e a segunda fizesse transparecer aqueles traços mais recônditos, a partir dos quais o mesmo cenário adquire conotações mais intimistas, transmitindo a sensação de estar ela em seus "aposentos". No limite, profissão e hobby dividem o mesmo espaço; criação literária e leitura contemplativa são retratadas como práticas indissociáveis, complementares e, sobretudo, como hábitos triviais. Nas palavras de José de Souza Martins ao referir-se aos retratos fotográficos (a exemplo do que parece caracterizar o processo de confecção do retrato artístico),

esse cuidado na apresentação pessoal do fotografado é
também uma racionalização vestimental com o objetivo de
fazer-se entender pelo "leitor" da fotografia e
preventivamente evitar que a vestimenta própria de um
certo código de decoro induza a leitura da foto segundo
uma pauta de entendimento que entre em conflito com
aquilo que o fotografado entende ser como pessoa e quer
dar a ver (Martins, 2008:15).

Tanto o retrato de Amoedo, quanto o de Hall, ao apreenderem Júlia Lopes em momentos de "suspensão do fazer literário", "eternizam" a espera como incômodo e, sobretudo, revelam seu contraponto: a produção literária como um processo contumaz, que não prevê interrupções.

Além disso, e sabendo que "a intensidade da ornamentação influi no sentido de gênero de um objeto" (Carvalho, 2008:45), a presença do vaso de flores em seu escritório/sala de leitura, assim como a elegância da decoração (vide imagem 9) permite-nos situar o cômodo a meio caminho entre o intimismo de um boudoir 
Júlia Lopes de Almeida em "retrato e prosa"

e o exibicionismo de uma sala de visitas (em outros termos, o hibridismo do ambiente poderia ser traduzido pela expressão private drawing room) e, para além disso, remete-nos a um aspecto pontuado por Juliet Kinchin, segundo o qual

a correlação entre feminilidade e Natureza foi simbolizada na sala de visitas e no vestiário feminino por meio da inclusão de flores, plantas (jardineiras, porta-samambaias, aquários), bem como natureza morta ou pintura de paisagem (1996:22). ${ }^{20}$

Assim, dentre os motivos ornamentais "fundamentais na atribuição de marcas femininas aos objetos", as flores ocupam lugar destacado:

Em todos os manuais encontramos referência a elas. As mulheres são exaustivamente representadas em fotografias ao lado de vaso de flores, portando buquês, com roupas estampadas com motivos florais. Manuais e artigos de revista ensinavam a confecção de flores de papel, utilizadas para enfeites de toda sorte. A presença de flores naturais na casa era praticamente obrigatória. Recém-colhidas do jardim bem cuidado, onde através de estreitos caminhos elas poderiam ser apreciadas, as flores enfeitavam o interior das salas e eram um sinal da pureza do ar e da presença permanente da mulher (Carvalho, 2008:88).

De um modo geral, as flores são constantemente evocadas nos escritos de Júlia Lopes, em alguns momentos acompanhadas por informações técnicas $e$ aconselhamentos marcadamente didáticos acerca de seu cultivo, irrigação, tal como ocorre em

${ }^{20}$ No original: "the axis between femininity and Nature was symbolized in the drawing room and boudoir through the inclusion of flowers, plantlife (jardinières, fern cases, aquaria), and still-life or landscape pictures" (tradução nossa). 
várias passagens de Correio da Roça (1913). ${ }^{21}$ Nesse romance epistolar, Fernanda, uma das protagonistas, mantém contato com sua amiga Maria por meio de cartas, já que esta, após enviuvar-se, $e$ dadas as urgências materiais daí decorrentes, viu-se obrigada a abandonar a cidade com suas quatro filhas, diga-se de passagem, ex-alunas do Colégio Sion, e a enfrentar a vida no campo. O contato com a rusticidade da nova realidade não desperta o interesse de Maria, e Fernanda atua como uma espécie de incentivadora da amiga, revelando em cada missiva a profundidade de seus conhecimentos sobre jardinagem. Em correspondência enviada a Joaninha, filha de Maria, a mais entusiasmada com as novas paisagens, Fernanda arrola uma vasta lista contendo nomenclaturas de roseiras, não sem asseverar à jovem interlocutora:

Não tenhas preguiça de ler a imensa nomenclatura que vou estender diante dos teus olhos, imaginando que tal conhecimento vai fazer parte da tua educação. Cada uma dessas rosas não é tanto um produto da natureza, como o símbolo de uma obra de arte. Devemos saber os seus nomes, como sabemos os das telas mais afamadas e os das mais afamadas estátuas. Ei-los: Anna de Diesbach, Archimèdes, Anna Wood, Aurora Boreal (...) A estas roseiras juntei a bela Armytage Moore, que adquiri este ano, e que tem dado abundantes e lindas rosas ao meu jardim (pp.53-54; destaques nossos).

\footnotetext{
${ }^{21}$ Júlia Lopes chegou a dedicar um volume ao tema, que recebeu o nome de Jardim florido, jardinagem e foi publicado em 1922. Além disso, no Livro das Noivas, o assunto aparece retratado na crônica "Floricultura" (1914:131), na qual a escritora ressalta que "apresentar uma rosa nova [em exposições de jardinagem] deve dar igual orgulho ao de expor uma tela onde brilhem talento $e$ arte, e ao de publicar um livro original e galante" (p.138). Também merece destaque o conto "A alma das flores", enfeixado no volume Ânsia eterna (1903) e dedicado a Lúcio de Mendonça, especialmente porque o tema reaparece, mas sob a ótica masculina: o cultivo de flores revela-se uma grande paixão do personagem Sales.
} 
Júlia Lopes de Almeida em "retrato e prosa"

Por seu turno, a reportagem "D. Júlia Lopes, a ilustre escritora, chega a Porto Alegre", publicada no jornal A Notícia, faz menção à passagem da escritora pela capital gaúcha, com vistas à realização de uma série de conferências. Merece destaque a imagem escolhida para ilustrar a divulgação (imagem 12), bem como o retrato fotográfico que, muito provavelmente a tenha originado (imagem 13), cujas semelhanças com a tela de Hall são inequívocas.

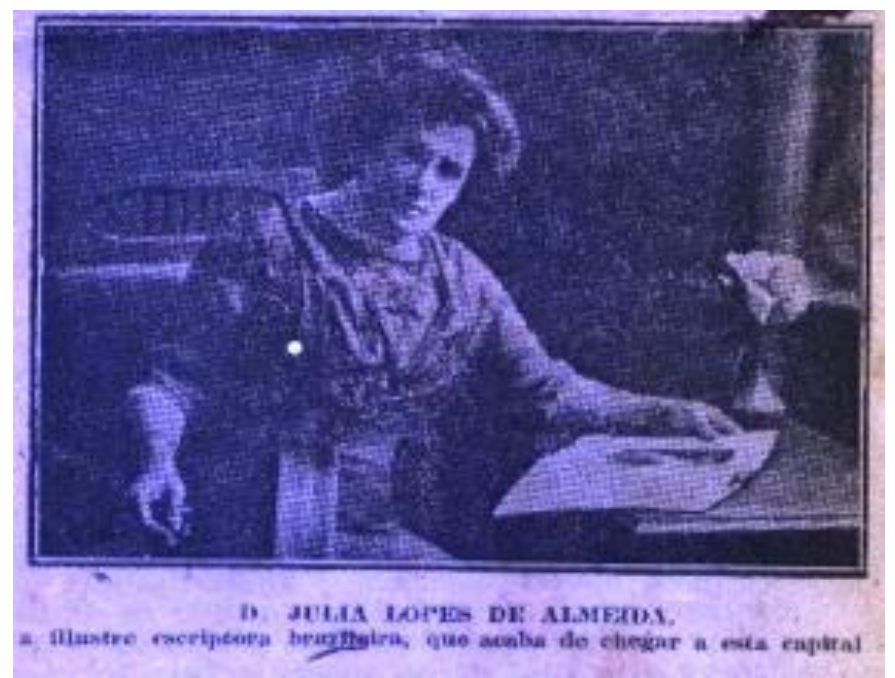

Imagem 12. Retrato fotográfico de Júlia Lopes publicado no jornal $A$ Notícia, de Porto Alegre [s.d.]. Legenda: "D. Júlia Lopes de Almeida - a ilustre escritora brasileira, que acaba de chegar a esta capital".

Como que surpreendida pela câmera fotográfica em seu escritório, em meio aos afazeres profissionais, Júlia Lopes parece haver procedido a rápidos retoques em seu visual. A despeito da obviedade das semelhanças, a diferença que esse retrato fotográfico mantém em relação à imagem 2 reside, muito provavelmente, em certa sensação de movimento que ambas as mãos da escritora aqui transmitem: a mão direita dá a entender 
que os óculos que ostenta haviam acabado de ser removidos de sua face, já que o braço se mantém levemente flexionado, tal como naqueles gestos ainda inconclusos; além disso, a mão esquerda segura um livro aberto, levemente arqueado, como se a escritora ameaçasse trazê-lo, muito sutilmente, para mais perto de si.

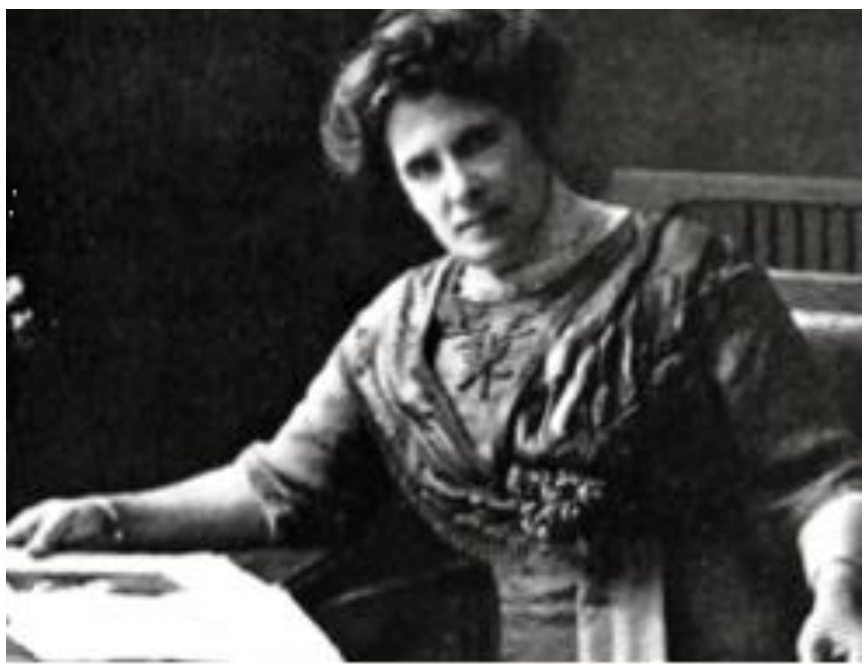

Imagem 13. Trata-se, por suporto, da fotografia a partir da qual a ilustração publicada no jornal A Notícia fora (re)produzida.

Observando as imagens 12 e 13, é possível concluir que a figura veiculada pela imprensa é uma reprodução do retrato fotográfico acima, e não apenas em função da desproporcional qualidade existente entre ambas, mas porque o processo de reprodução da imagem resultou em sua inversão. Para tanto, basta considerar-se, por exemplo, a disposição da mobília que compõe o escritório/sala de leitura de Júlia Lopes (imagem 9), para que seja possível perceber que o registro estampado no jornal A Notícia derivou da imagem $13 .{ }^{22}$

${ }^{22}$ Quanto a isso, cabe aqui um parêntesis: o famoso ensaio de Benjamin (1996:101; 166-167), no qual o filósofo reflete sobre "a obra de arte na era de 
Júlia Lopes de Almeida em "retrato e prosa"

Outro ponto a ser destacado diz respeito às dimensões da imagem 12, que acaba por compensar, de alguma forma, sua falta de nitidez. ${ }^{23}$ Tanto que nela, nota-se a presença de um vaso de flores a adornar a mesa em que Júlia Lopes encaminha sua leitura, - elemento esse, como dito, carregado de simbologia, na medida em que pode ser apreendido como um gendered object.

Considerando-se o conjunto documental até aqui analisado, a "apresentação pessoal" de Júlia Lopes revela-se um expressivo índice analítico, ainda mais quando se tem em vista o quanto a moda, ao longo do século XIX, concorreu para a intensificação do "dimorfismo estético" (Pontes, 2004:32), i.e., para o distanciamento entre os grupos masculino e feminino (Souza, 1987). Nas palavras de Souza, "um conjunto diverso de tecidos e de cores, restrito para o homem" revelou-se, então, "abundante para a mulher, exilando o primeiro numa existência sombria onde a beleza está ausente, enquanto afoga a segunda em fofos e laçarotes" (1987:71-72; Cf. Bourdieu, 2003:118). Acompanhando, pois, essa linha de argumentação, não parece arriscado afirmar que, no concernente à "gestão da imagem", a indumentária que Júlia Lopes exibe nos diferentes retratos, longe de exprimir e/ou guardar correspondência, em termos de forma, tecido e cores, com aquele conjunto de mudanças às quais a autora se refere, dele destoa, e em virtude de seus traços característicos, dentre os quais se "sobressaem" a discrição e a sobriedade (não apenas

sua reprodutibilidade técnica", propõe, de saída, a diferenciação entre imitação, apresentada como prática constitutiva do fazer artístico, e reprodução técnica, processo moderno que faculta a massificação das imagens (cf. FABRIS, 1991:22). Daí ser impossível pensar a fotografia senão enquanto produto $e$ expressão da sociedade industrial (Martins, 2008). A propósito das diferenças entre a fotografia original e sua reprodução, cf. Kossoy, 2003:40-41.

${ }^{23}$ Não há dúvidas de que a imagem "de primeira geração" de que dispomos sofreu alguma espécie de edição, comprometendo a visualização de importantes elementos da composição. 
quanto à ornamentação, mas quanto à variação cromática ou, mais propriamente, a sua falta). ${ }^{24}$

Sabendo, pois, que o processo de execução de um retrato supõe "uma complexa negociação ente o artista e o retratado, ambos imersos nas circunstâncias em que se processou a fatura da obra", as imagens de Júlia Lopes traduzem com considerável êxito aquele conjunto de "expectativas" e aspirações relacionadas à exibição de sua "imagem pública", enfim, "aos ganhos de toda ordem" que a escritora poderia auferir a partir de sua "representação visual", enfim, "aos manejos dos sentidos que [pretendeu] infundir (...) nos parâmetros de sua leitura $e$ interpretação" (Miceli, 2006:18).

Sob esse aspecto, e ilustrativa do interesse de Júlia Lopes pelas artes plásticas, o que até mesmo justificaria seu investimento pessoal na aquisição de autorretratos, a crônica "Belas Artes", anteriormente citada, traz como eixo narrativo o diálogo entre duas amigas, cuja tônica é a exibição de suas predileções estéticas e juízos de gosto. ${ }^{25}$ Condenando veementemente a prática da oleografia, a narradora não apenas revela, sem volteios, sua "intolerância estética" (Bourdieu, 2008:57) para com esse procedimento que "parasita" as artes, como demarca sua distância, em termos de capital cultural acumulado, em relação a sua amiga/interlocutora que, "aliás inteligente, relembrava as molduras douradas $e$ as sendas veil-or do salão principesco do riquíssimo barão X", ao passo que "eu lamentava que ela não tivesse tido a

${ }^{24}$ Tal como observa Souza, "lançando-se no áspero mundo dos homens, a mulher viu-se dilacerada entre dois polos, vivendo simultaneamente em dois mundos, com duas ordens inversas de valores. Para viver dentro da profissão adaptou-se à mentalidade masculina da eficiência e do despojamento, copiando os hábitos do grupo dominante, a sua maneira de vestir, desgostando-se com tudo aquilo que, por ser característica de seu sexo, surgia como símbolo de inferioridade: o brilho dos vestidos, a graça dos movimentos, o ondulado do corpo" (1987:106).

${ }^{25}$ A fala da protagonista oferece elementos por meio dos quais é possível perceber como se opera a imposição de determinada percepção artística como legítima, bem como a relação de distinção por ela engendrada (Bourdieu, 2008:11). 
Júlia Lopes de Almeida em "retrato e prosa"

finura de se rir das oleografias exoticamente postas entre uns espelhos límpidos, sobre um papel de preço" (Almeida, 1914:42).

Uma pintura original, uma aquarela, um busto, uma estátua, qualquer dessas divinas coisas que nos enlevam $e$ nos consolam, que vêm trazer-nos do espírito do seu autor uma centelha que ilumine o nosso, um agasalho que envolva o nosso coração, como um bafo morto a uma ave friorenta, isso sim, que é digno de termos na intimidade da nossa sala de conversa ou de trabalho (...) Ter uma oleografia numa sala, dizia-me há dias meu marido, equivale a usar um pedaço de vidro verde no anel, à laia de esmeralda... (id.ib:43).

Ao expor seus conhecimentos artísticos, a narradora apresentase como detentora do bom gosto, lamenta a falta de curiosidade e de educação "artística" dos brasileiros e credita à Escola Nacional de Belas Artes a tarefa de contribuir para "o aperfeiçoamento e o desenvolvimento do espírito" de seus compatriotas: ${ }^{26}$

Felizmente, a nossa Escola Nacional de Belas Artes, sob o influxo inteligente dos artistas novos, instituiu com êxito as exposições anuais, que serão, estou certa, o início da educação do nosso gosto. São por enquanto modestas, essas exposições, mas também modesto é o nosso meio artístico. O tempo, o estímulo e a animação dos amadores farão que elas progressivamente aumentem de valor e de

\footnotetext{
${ }^{26}$ A referência de Júlia Lopes à Escola Nacional de Belas Artes não parece fortuita. Basta, para tanto, lembrar que, diferentemente da Academia Imperial de Belas Artes, sua sucessora republicana permitiu legalmente o acesso feminino à instrução artística. Nas palavras de Simioni, "ao longo do Império, os integrantes do sexo feminino estiveram totalmente impedidos de ter acesso a uma educação nos moldes daquela ao alcance dos homens, posto que a Academia Imperial de Belas Artes não previa essa possibilidade em seu corpo discente", de modo que "somente com a República, mais precisamente, em 1893, elas foram legalmente previstas na mais importante instituição consagrada à formação artística existente em território nacional: a Escola Nacional de Belas Artes” (2008:31).
} 
importância artística. Mas é já um consolo o sabermos que em setembro de todos os anos poderemos ter uma ideia do movimento e dos progressos da arte nacional; poderemos ir ali recrear a nossa vista e gozar das emoções que a arte produz em todas as organizações sensíveis (id.ib.:45).

Para finalizar esta seção, vale chamar a atenção para a tela Retrato de Júlia Lopes de Almeida (imagem 14), assinada pela artista plástica francesa Berthe Worms (1868-1937) e exposta em 1895, na II Exposição Geral de Belas Artes, organizada pela ENBA, no Rio de Janeiro, já que nela, a alusão às flores parece atingir seu auge. ${ }^{27}$ É nítido o quanto a delicadeza, a leveza e a brandura da imagem contrastam com a "aspereza" da postura e com a seriedade dos traços fisionômicos que as demais telas "comunicam". É, aliás, revelador que o único retrato artístico de Júlia Lopes despido de qualquer referência direta ao seu universo profissional e/ou literário tenha sido executado justamente por uma artista plástica.

\footnotetext{
${ }^{27}$ Além dessa, duas outras telas assinadas pela artista plástica francesa participaram do evento, quais sejam Lição Difícil e Cabeça de Cardeal, "sendo a última laureada com um admirável prêmio: a segunda medalha de ouro" (SIMIONI, 2008:234). Conforme nos informou Cláudio Lopes de Almeida, o Retrato de Júlia Lopes de Almeida foi confeccionado quando a escritora contava 33 anos, coincidindo, portanto, com a data em que foi exposto (1895).
} 
Júlia Lopes de Almeida em "retrato e prosa"

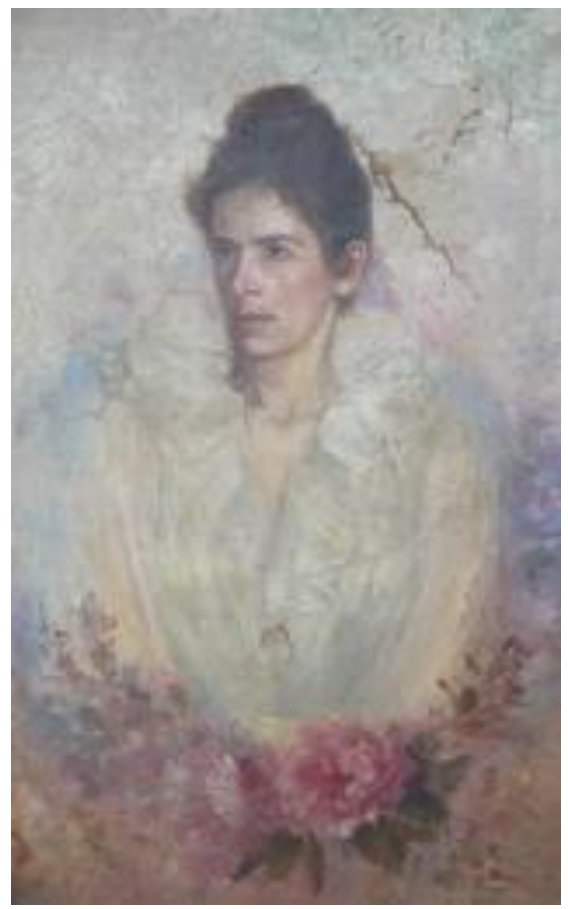

Imagem 14. Retrato de Júlia Lopes de Almeida, pintado por Berthe Worms, em 1895, e oferecido pela retratista à escritora.

Malgrado a "limpidez" da imagem, i.e., a ausência de objetos, enfeites, artefatos, sua profundidade parece residir no fato de Júlia Lopes ter sido retratada, ela mesma, como um adorno. A referência mais explícita é ao "botão de rosa" a irromper, soberano, sobre uma modesta ramagem. Com efeito, a despretensão dessa metáfora revela-se aparente, sobretudo porque, tal como citado, a própria escritora, na voz da personagem Fernanda, enxerga nas rosas "não tanto um produto da natureza, como o símbolo de uma obra de arte. Devemos saber os seus nomes, como sabemos os das telas mais afamadas e os das mais afamadas estátuas" (Almeida, 1913:54; destaques nossos). 
Para além disso, os tons claros e perolados da imagem como que evocam, mais indiretamente, aquela joia com a qual a escritora sempre se identificou (seus retratos não deixam margem à dúvida quanto a essa predileção), donde converter-se pictoricamente em pérola é, por assim dizer, poetizar/estetizar sua própria existência.

\section{Considerações finais}

A despeito das restritas possibilidades de letramento feminino durante a belle époque tropical, deparamo-nos, de modo contrapontístico, com uma série de imagens de Júlia Lopes (retratos artísticos, fotográficos e até mesmo dois desenhos) que "dialogam entre si" ao reforçarem a associação entre "mulher" $e$ "escrita", entre "mulher" $e$ "arte". Considerando-se, pois, a recorrência com que a temática da profissionalização feminina aparece em suas crônicas, os investimentos pessoais da escritora na conformação desse repertório imagético se nos afigura como um recurso estético/visual complementar valioso, com vistas não apenas à fruição de sua imagem no âmbito doméstico, mas também à sua projeção pública. Além disso, e curiosamente, as fotografias muito se assemelham àqueles retratos executados pelos artistas plásticos, i.e., as similitudes visuais entre tais registros parecem amainar suas diferenças técnicas.

Dito de outra forma, o fazer literário e a leitura não são apenas temáticas características da fatura literária de Júlia Lopes de Almeida, mas transbordam para os registros pictóricos a seu respeito. Essas imagens "perenizam" Júlia Lopes como escritora/leitora, como apreciadora das artes, "em todas as suas organizações sensíveis" (Almeida, 1914), especialmente ao nos fornecer registros a partir dos quais o universo artístico é anunciado como sendo seu universo, par excellence, no qual criação literária e lapidação do conhecimento se definem como atividades cotidianas e regulares. 
Júlia Lopes de Almeida em "retrato e prosa"

No caso específico das fotografias, além de cenograficamente alinhadas, tais imagens não parecem resultantes de uma "captação espontânea" (Leite, 1993:45) da retratada, especialmente porque todas recendem certa preocupação cênica que não pode ser pensada se desvinculada da intencionalidade de que são portadoras, ao exprimirem o empenho $e$ investimento de Júlia Lopes na conformação de um "corpus documental" capaz de eternizar e fazer circular imagens de si cujos conteúdos reiterassem sua relação com o mundo das letras. Em outros termos, tais retratos "atesta[m] um desejo e uma ação deliberada de registrar aquilo que deve[ria] ser objeto de rememoração pela posteridade" (Schapochnik, 2006:462).

Destarte, é possível mencionar que as imagens aqui analisadas, ao insinuarem o modo como Júlia Lopes desejava ser reconhecida e apreendida, "comunicam uma atmosfera $e$ exprimem sentimentos" (Leite, 1993:46) e, para além disso, transmutam aqueles "reclamos e apelos" da escritora em composição plástica. No mais das vezes retratada em seu ambiente de trabalho, a ostentar "objetos simbólicos" que, a um só tempo, se apresentam como "objetos biográficos", sempre alusivos ao seu pertencimento ao universo literário: óculos, livros, folhas ainda em branco (estas, estrategicamente dispostas, de modo a anunciarem o momento pregresso à feitura de uma nova obra literária). Contudo, e o que é indispensável destacar, a presença de artefatos que suavizam a aspereza dos "espaços masculinos", tal o caso da almofada, do piano, do módulo que complementa a poltrona e das miniaturas decorativas, assim como daqueles ornamentos que guardam correspondência com $\mathrm{O}$ universo feminino, tais como as flores, as pérolas, o broche etc., parecem exprimir a atenção que Júlia Lopes dispensou à "exibição flagrante e/ou emoldurada" das correspondências, "ajustes" e "compassos" entre "mulher" e "arte", entre "mulher" e "profissionalização literária". 


\section{Referências bibliográficas}

Austregésilo, Antônio. Perfil da mulher brasileira. Esboço acerca do feminismo no Brasil. Rio de Janeiro, Livraria Francisco Alves, 1923.

BENJAMIN, Walter. Magia e técnica, arte e política: ensaios sobre literatura e história da cultura. Obras escolhidas vol. 1. São Paulo, Brasiliense, 1996.

BosI, Ecléa. Objetos. In: BosI, Ecléa. Memória e Sociedade: Lembranças de Velhos. São Paulo, Companhia das Letras, 1994, pp.441-442.

BOURDIEU, Pierre. As regras da arte. Gênese e estrutura do campo literário. São Paulo, Companhia das Letras, 1996.

. A dominação masculina. Rio de Janeiro, Bertrand Brasil, 2003

. A distinção: crítica social do julgamento. São Paulo, EDUSP/Porto Alegre, RS, ZOUK, 2008.

BURKE, Peter. Testemunha ocular: história e imagem. Bauru, SP, EDUSC, 2004.

CarvalHo, Vânia Carneiro de. Gênero e artefato. O sistema doméstico na perspectiva da cultura material - São Paulo, 1870-1920. São Paulo, EDUSP/FAPESP, 2008.

e LiMA, Solange Ferraz de. Individuo, Género y Ornamento en los Retratos Fotográficos, 1870-1920. In: AGUAYO, Fernando \& RocA, Loures (org.). Imágenes e Investigación Social. México, Instituto Mora, 2005, pp.271-291.

CORRÊA, Mariza. Antropólogas \& Antropologia. Belo Horizonte, Editora UFMG, 2003.

DE LUCA, Leonora. O feminismo possível de Júlia Lopes de Almeida (1862-1934). Cadernos Pagu (12), Campinas-SP, Núcleo de Estudos de Gênero - Pagu, 1999, pp.275-299.

ELEUTÉRIO, Maria de Lourdes. Vidas de romance: as mulheres e o exercício de ler e escrever no entresséculos. Rio de Janeiro, TOPBOOKS, 2005. 
Júlia Lopes de Almeida em "retrato e prosa"

FABRIS, Annateresa. Fotografia: usos e funções no século XIX. São Paulo, EDUSP, 1991.

INL - Instituto Nacional do Livro, Brasília, 1987. [1913]

KINCHIN, Juliet. Interiors: Nineteenth-Century Essays on the Madculine and Feminine Room. In: KIRKHAM, Pat (ed.). The gendered object. Manchester/New York, Manchester University Press, 1996.

Kossoy, Boris. Fotografia \& História. São Paulo, Ateliê Editorial, 2003.

LEITE, Miriam Moreira. Retratos de Família: Leituras da Fotografia Histórica. São Paulo, EDUSP, 1993.

MARTINS, José de Souza. Sociologia da fotografia e da imagem. São Paulo, Contexto, 2008.

MICELI, Sergio. Imagens negociadas: retratos da elite brasileira (19201940). São Paulo, Companhia das Letras, 2006.

MOREIRA, Nadilza. A condição feminina revisitada: Júlia Lopes de Almeida e Kate Chopin. João Pessoa, Editora Universitária/UFPB, 2003.

PAIXÃO, Sylvia Perlingeiro. Introdução. In: AlMEIDA, Júlia Lopes. Correio da Roça: romance epistolar. Rio de Janeiro, Presença Edições/Brasília, INL - Instituto Nacional do Livro, 1987 (1913).

POLLACK, Michael. Memória, esquecimento, silêncio. Estudos Históricos (3), Rio de Janeiro, 1989, pp.3-15.

PONTES, Heloisa. Modas e modos. Uma leitura enviesada de $O$ espírito das roupas. Cadernos Pagu (22), Campinas-SP, Núcleo de Estudos de Gênero - Pagu, jan/jul 2004, pp.13-46.

RoQuette, José Inácio. Código do Bom-Tom, ou, Regras da civilidade e de bem viver no século XIX. São Paulo, Companhia das Letras, 1997. Organização de Lilia SCHWARCZ.

SALOMONI, Rosane Saint-Denis. Introdução. In: AlmEIDA, Júlia Lopes de. Memórias de Marta. Florianópolis, SC, Ed. Mulheres, 2007.

SAMAIN, Etienne. Apresentação: um espelho surpreendente. In: SAMAIN, Etienne (org.). O fotográfico. São Paulo, Editora HUCITEC/Editora SENAC, 2005. 
SCHAPOCHNIK, Nelson. Cartões-postais, álbuns de família e ícones da intimidade. In: SEVCENKO, Nicolau (org.) História da vida privada no Brasil 3. República: da Belle Époque à era do Rádio. São Paulo, Companhia das Letras, 2006. [1998]

SimIONI, Ana Paula Cavalcanti. Profissão artista: pintoras e escultoras acadêmicas brasileiras. São Paulo, EDUSP/FAPESP, 2008.

SouZA, Gilda de Mello e. O espírito das roupas: a moda no século dezenove. São Paulo, Companhia das Letras, 1987.

\section{Fontes documentais}

Arquivo pessoal de Júlia Lopes de Almeida, sob a guarda de Claudio Lopes de Almeida.

AlmeIDA, Filinto de. Dona Júlia. Rio de Janeiro, Typ. do Jornal do Commercio, 1938.

AlmeIDA, Júlia Lopes de. A alma das flores. In: Ânsia eterna. Rio de Janeiro, H. Garnier, 1903.

- Livro das donas e donzelas. Rio de Janeiro, Livraria Francisco Alves, 1906.

1914. [1896]

. Livro das Noivas. Rio de Janeiro, Livraria Francisco Alves, . Eles e Elas. Rio de Janeiro, Livraria Francisco Alves, 1922. [1910].

- Correio da roça: romance epistolar. Rio de Janeiro, Presença Edições; 